\title{
Unregulated Deep-Sea Fisheries: A Need for a Multi-Level Approach
}

\author{
E.J. Molenaar* \\ Netherlands Institute for the Law of the Sea (NILOS), Utrecht \\ University and Institute of Antarctic and Southern Ocean Studies \\ (IASOS), University of Tasmania
}

\begin{abstract}
Many deep-sea fisheries share characteristics that distinguish them from other fisheries in a way which heightens sustainability and biodiversity concerns. Due to their depth of operation, many deep-sea fisheries occur in areas where the current international law of the sea gives coastal states no jurisdiction to regulate fisheries unilaterally. Whereas many international fisheries currently suffer from unregulated fishing under irresponsible flags of convenience, the concerns on deep-sea fisheries relate first of all to the absence of (international) regulation. The approach advocated in this article would be one where complementary action is taken simultaneously at the global, regional and national levels. As there may not be enough time for conceptually sound and holistic but incremental processes for regime building, the focus should first of all be on flexible short-term action.
\end{abstract}

\section{Introduction}

The strong growth in deep-sea fishing activity witnessed during the last decade is largely a consequence of technological innovations (the "era of surgical fishing"), the continued worldwide over-capacity in fishing effort, increasing overexploitation of traditional fish species and increasing global demand for fish products. Although there is no single generally accepted definition of deep-sea fisheries, the International Council for the Exploration of the Sea (ICES) regards these as fisheries operating at depths greater than 400 metres. ${ }^{1}$ Many deep-sea fisheries share characteristics that distinguish them from other fisheries in a way which heightens sustainability and biodiversity concerns.

* The author is very grateful for comments by N. Bouffard, I. Hay, M. Lodge, R. Long, A. Macfarlane and A. Serdy on an earlier version of the article. The author remains entirely responsible for the current text.

Cf. "Is Time Running Out for Deep-Sea Fish?", available at: http://www.ices.dk.

THE INTERNATIONAL JOURNAL OF MARINE AND COASTAL LAW, Vol 19, No 3

(C) Koninklijke Brill NV, 2004 
First, they often target long-lived and slow-growing species with late maturity and low fecundity, with consequential high risks of over-exploitation and the collapse of stocks. These risks are further increased by the fact that scientific understanding of the biological characteristics of many deep-sea species is generally very limited. This has serious implications for the adequacy of stock assessment models. The biodiversity concerns are particularly acute for species or populations with small ranges of distribution, as often seems to be the case with species that aggregate around seamounts.

Secondly, as many of the target species are demersal, the use of certain fishing practices such as bottom trawling can have considerable ecosystem effects, for instance bycatch of other sedentary species and impacts on the seabed and subsoil (e.g. deep-water coral reefs). The ecosystem effects of these fishing practices may also lead to biodiversity concerns.

Thirdly, and this leads to the core of this article, due to their depth of operation, a considerable proportion of deep-sea fisheries takes place in areas where the current international law of the sea gives coastal states no jurisdiction to regulate fisheries unilaterally. In view of the fact that both coastal states and high seas fishing states have rights and obligations with respect to straddling deep-sea fish stocks and discrete high seas deep-sea fish stocks, ${ }^{2}$ their regulation must take place at the international level. As the effectiveness of international regulation is seriously constrained by its consensual nature, culminating in "lowest common denominator", "free rider" and "prisoner's dilemma" problems, this makes deep-sea fisheries even more problematical. This does not mean, as is by now widely recognised, that unilateral coastal state authority is a sufficient guarantee for sustainable fisheries.

In recent years the international community has become more and more aware of and concerned by the sustainability of deep-sea fisheries and their threat to marine biodiversity. Such concern was inter alia expressed by the focus on protecting vulnerable marine ecosystems at the Fourth Meeting (2003) of the UN's Open-Ended Informal Consultative Process (ICP) on Oceans and the Law of the Sea, ${ }^{3}$ by the latest United Nations General Assembly (UNGA) Resolution on Oceans and the Law of the Sea, ${ }^{4}$ by "Deep

2 Straddling stocks are generally accepted to be the stocks mentioned in Art. 63(2) of the LOS Convention (United Nations Convention on the Law of the Sea, Montego Bay, 10 December 1982; in force 16 November 1994, text published in 1833 United Nations Treaty Series 396; text is also available at: http://www.un.org/Depts/los). Shared deep-sea fish stocks within the meaning of Art. 63(1) of the LOS Convention - thus involving exclusively coastal statesare left beyond the scope of discussion.

3 UN Doc. A/58/95 of 26 June 2003. See inter alia paras. 1, 13, 20, 21(d) and 22 on pp. 1, 6 and 8 and paras. 80-81, 87-89, 94, 98-100. See also the 2002 Report of the UN Secretary-General on "Oceans and the Law of the Sea" (UN Doc. A/58/65 of 3 March $2003)$, pp. 52-70 and especially paras. $183-184,191-192,197-205,222-223,228-231$.

4 See paras. 51-52, 57 and 68 of UNGA Resolution 58/240 (Doc. A/RES/58/240 of 5 March 2004) and para. 46 of UNGA Resolution 58/14 (Doc. A/RES/58/14 of 21 January 2004). 
Sea 2003"- an international conference held in Queenstown, New Zealandin early December $2003^{5}$ and by the 7 th Meeting of the Conference of the Parties (COP7) $)^{6}$ to the Biodiversity Convention ${ }^{7}$ in February $2004 .^{8}$ The focus on "new sustainable uses of the oceans, including the conservation and management of the biological diversity of the seabed in areas beyond national jurisdiction" at the Fifth ICP Meeting (2004) $)^{9}$ is expected to be a further step in this regard.

This article examines whether, in view of the special characteristics of deepsea fisheries, the present international legal regime and state practice, there is a need to develop new international law and/or for more widespread, consistent or pro-active application of existing international law. The next section gives a succinct analysis of the present international legal regime and state practice on the basis of which the subsequent section proposes a multi-level approach to enhance the sustainability of deep-sea fisheries and to lessen the threats to marine biodiversity. The article ends with some conclusions and observations.

\section{The Present International Legal Regime and State Practice}

The present international legal regime that applies to deep-sea fisheries that target straddling and discrete high seas deep-sea stocks is not laid down in a single treaty. Rather, it consists of a multitude of global, regional and bilateral treaties with diverging objectives as well as legally binding acts from various global and regional intergovernmental organisations (IOs). Particularly relevant IOs at the regional level are regional fisheries management organisations (RFMOs). ${ }^{10}$ In addition, many non-legally binding international instruments and acts of IOs have relevance as well.

5 For info, the Interim Report and the full conference Report, see www.deepsea.govt.nz. For the papers, see R. Shotton (ed.), "Proceedings of the Deep Sea 2003 Conference" (FAO, Technical Report (2004), forthcoming).

6 See inter alia paras. 30 and 57-62 of Decision VII/5, "Marine and Coastal Biological Diversity" (Doc. UNEP/CBD/COP/7/21 of 13 April 2004, p. 134 ff ).

7 Convention on Biological Diversity, Nairobi, 22 May 1992. In force 29 December 1993, text reproduced in (1992) 31 International Legal Materials 822, and also available at: http://www.biodiv.org.

8 See also M. Lack, K. Short and A. Willock, "Managing Risk and Uncertainty in Deep-Sea Fisheries: Lessons from Orange Roughy" (Traffic Oceania and WWF Endangered Seas Programme, 2003; see also at http://www.wwf.org.au and http://www.traffic.org) and the info and initiatives at http://europe.oceana.org.

9 See UN Doc. A/AC.259/L.5, "Format and Annotated Provisional Agenda" of 1 April 2004, Annex III.

10 For the purpose of this article, unless specified otherwise, the acronym RFMO is meant to cover "arrangements" in the sense of Art. 1(d) of the Fish Stocks Agreement (Agreement for the Implementation of the Provisions of the United Nations Convention on the Law of the Sea of 10 December 1982 Relating to the Conservation and Management of Straddling Fish Stocks and Highly Migratory Fish Stocks, New York, 4 August 1995. In force 11 December 2001, text published in (1995) 34 ILM 1542; text also available at: http://www un.org/Depts/los. 
The basic international legal framework for deep-sea fisheries is provided by the LOS Convention. This convention recognises the sovereignty, sovereign rights and jurisdiction of coastal states with respect to marine living resources within their maritime zones ${ }^{11}$ and the right for all states for their nationals to engage in fishing on the high seas. ${ }^{12}$ These rights are qualified by obligations owed to each other ${ }^{13}$ and to the international community. The latter obligations are aimed to safeguard such international community interests as conservation and optimum utilisation of marine living resources and the protection and preservation of the marine environment, including rare or fragile ecosystems and habitats of depleted, threatened or endangered species and other forms of life. ${ }^{14}$

Among the large number of relevant treaties, two global treaties are particularly relevant. These are the Fish Stocks Agreement ${ }^{15}$ and the Biodiversity Convention. The Fish Stocks Agreement applies exclusively to straddling fish stocks and highly migratory fish stocks and therefore not to discrete high seas fish stocks. ${ }^{16}$ Both treaties contain provisions that ensure that the jurisdictional framework of the LOS Convention is left unaffected. ${ }^{17}$ The reality is, however, that while the basic fishing entitlements of the LOS Convention remain unaltered, international legal developments since the adoption of the LOS Convention have made the exercise of these entitlements increasingly qualified. The widening and deepening of relevant obligations is also evident in these two treaties, for instance their basic obligations to conserve biological diversity and to apply the precautionary approach. ${ }^{18}$ In addition, the key role accorded to RMFOs under Article 8 of the Fish Stocks Agreement is intended to eventually lead to a situation where (high seas) fishing can only be engaged in by vessels flying the flag of states that are members of RFMOs or that cooperate with them. ${ }^{19}$

In spite of these positive developments, however, the effectiveness of the regulation of international marine fisheries is constrained by the consensual nature of international law. In the context of the principle of exclusive jurisdiction of flag states on the high seas and the wide flag state discretion in granting its nationality to ships, ${ }^{20}$ this consensual nature has led to severe

Arts. 2(1), 49(1), 56(1)(a), 56(3) and 77 of the LOS Convention.

Art. 116. See also Art. 92(1).

E.g. Arts. 63(2) and 116(b).

See e.g. Arts 61(2), 62(1), 117-119, 192 and 194(5) of the LOS Convention.

See note 10 above.

This is already evident from the full title of the Agreement (see note 10 above). See also Arts. 2 and 3.

17 Art. 4 of the Fish Stocks Agreement and Art. 22 of the Biodiversity Convention.

18 Arts. 1 and 6 of the Biodiversity Convention and Arts. 5(c) and 6 and Annex II to the Fish Stocks Agreement. See also notes 61-65 below and accompanying text.

19 Cf. Art. 8(4) of the Fish Stocks Agreement.

20 See Arts. 91-92 of the LOS Convention. 
"lowest common denominator", "free rider" and "prisoner's dilemma" effects. These effects are evident in the increasing problems posed by illegal, unreported and unregulated (IUU) fishing to marine capture fisheries worldwide. This is particularly true for unregulated fishing within the meaning of paragraph 3.3.1 of the IPOA on IUU Fishing. ${ }^{21}$ There, unregulated fishing essentially refers to fishing activity under the flag of (non-co-operating) non-members of RFMOs. Until the Fish Stocks Agreement enjoys (quasi-) universal participation by states that fully comply with its obligations, in particular those in Article 8 in relation to RFMOs, this is expected to remain a considerable problem in the foreseeable future.

However, it is submitted that unregulated fishing in the sense of fishing in the absence of specific (international) regulation but inconsistent with broader state responsibilities, or even with legal obligations, ${ }^{22}$ is at the moment actually a more serious problem for deep-sea fisheries. Clearly, in the absence of regulation by RFMOs, fishing cannot be inconsistent with or contravene any measures and thereby amount to unregulated fishing within the meaning of paragraph 3.3.1. The absence of international regulation can in part be explained by the fact that deep-sea fishing is a relatively new type of fishing. So far, the only example of international regulation with an exclusive focus on deep-sea fisheries seems to be the bilateral 2000 South Tasman Rise Orange Roughy ${ }^{23}$ Arrangement between Australia and New Zealand. ${ }^{24}$

Only a few of the RFMOs that are currently operating would in principle have competence to deal with straddling and discrete high seas deep-sea fish stocks. ${ }^{25}$ Of these, only the Commission for the Conservation of Antarctic

21 International Plan of Action to Prevent, Deter and Eliminate Illegal, Unreported and Unregulated Fishing. Adopted by consensus by FAO's Committee on Fisheries on 2 March 2001 and endorsed by the FAO Council on 23 June 2001; text available at: http://www. fao.org/fi.

22 See para. 3.3.2 of the IPOA on IUU Fishing.

23 Hoplostethus atlanticus.

24 Arrangement between the Government of Australia and the Government of New Zealand for the Conservation and Management of Orange Roughy on the South Tasman Rise. Signed for New Zealand on 17 February 2000 and for Australia on 25 February 2000. In effect on 1 March 2000; reproduced in (2001) 16 International Journal for Marine and Coastal Law 119-123. For a discussion see E.J. Molenaar, "The South Tasman Rise Arrangement of 2000 and Other Initiatives on Management and Conservation of Orange Roughy", (2001) 16 IJMCL 77-118.

25 In addition to CCAMLR, NAFO and NEAFC (mentioned in the main text below), this would seem to include the GFCM (Agreement for the Establishment of a General Fisheries Council for the Mediterranean, Rome, 24 September 1949. In force 20 February 1952, 126 UNTS 239; amended version available at: http://www.fao.org/fi/body/rfb/GFCM/gfcm basic.htm; the new GFCM Agreement that was adopted by the FAO Council at its 113th Session in November 1997 is not yet in force (text at http://www.oceanlaw.net)); the SEAFO (established by the Convention on the Conservation and Management of the Fishery Resources in the South-East Atlantic Ocean, Windhoek, 20 April 2001; in force 13 April 2003, 41 ILM 257 (2002); see http://faolex.fao.org; see Arts. 1(1) and 2; not yet operational); and the Commission to be established under the Framework Agreement for the Conservation of the Living Marine Resources on the High Seas of the South-East Pacific ("Galapagos Agreement"; Santiago, 
Marine Living Resources (CCAMLR), ${ }^{26}$ the Northwest Atlantic Fisheries Organization (NAFO) ${ }^{27}$ and the North-East Atlantic Fisheries Commission $(\mathrm{NEAFC})^{28}$ seem to have actually exercised that competence so far. This does not mean that a need to regulate deep-sea fisheries will arise or has already arisen within the regulatory area of all or most existing RFMOs. However, in areas where such a need does arise and a competent RFMO is not in place, the characteristics of deep-sea fisheries are such that they may no longer exist once the international institutions are operational. An example is the negotiation of the establishment of a South-West Indian Ocean Commission (SWIOFC), where progress has so far been very slow. ${ }^{29}$ The lucrative orange roughy fishing grounds which triggered one of the two SWIOFC negotiating tracks have by now been exhausted. ${ }^{30}$ It is admitted, however, that the nature and history of these negotiations, especially the two tracks that were initially operating in isolation from and in ignorance of each other and the difficulty of integrating the fundamentally different objectives of these two tracks, contributed greatly to this lack of progress.

Whereas a comprehensive examination of global state practice on the regulation of deep-sea fisheries has not been carried out, ${ }^{31}$ the overall impression is nevertheless that, so far, both national and international regulation of deepsea fisheries has often been too little, too late and insufficiently cautious to

cont.

14 August 2000; not in force, (2001) Law of the Sea Bulletin 45, 70-78; see http://www. oceanlaw.net/texts/index.htm; Art. 4).

26 Established by the Convention on the Conservation of Antarctic Marine Living Resources (Canberra, 20 May 1980; in force 7 April 1982, text reproduced in (1980) 19 ILM 837; see also http://www.ccamlr.org). For CCAMLR's competence see Arts. I and II.

27 Established by the Convention on Future Multilateral Co-operation in the North-West Atlantic Fisheries, Ottawa, 24 October 1978. In force 1 January 1979, 1135 UNTS 369; http://www.nafo.ca; see Art. I(4).

28 Established by the Convention on Future Multilateral Co-operation in the North-East Atlantic Fisheries (London, 18 November 1980; in force 17 March 1982, 1285 UNTS 129; http:// www.neafc.org; Art. 1(2)).

29 The third intergovernmental consultation took place between 27-30 January 2004, more than two years later than envisaged by the second consultation in September 2001 (cf. FAO Fisheries Report No. 664, para. 20, p. 26). Nevertheless, the third consultation was a breakthrough in the sense that it was decided to once again split the negotiation process into two tracks. One track will aim at establishing an advisory body under Art. VI of the FAO Constitution with an area of competence that will exclusively encompass coastal state maritime zones. The other track will aim at establishing a non-FAO RFMO or legally binding arrangement whose regulatory area will exclusively encompass high seas. Linkages will be made to ensure compatibility in the management of straddling stocks. (cf. Report of the Third Intergovernmental Consultation on the Establishment of a Southwest Indian Ocean Fisheries Commission, Nairobi, Kenya, 27-30 January 2004; draft as approved on 30 January 2004; on file with author). The fourth consultation is scheduled to take place between 12-16 July 2004, in the Seychelles (info kindly provided by A. Harris, FAO).

30 For a discussion of the initial stages of the negotiations see Molenaar, note 24 above, pp. 109-115. See also Lack, et al., note 8 above, pp. 37-40.

31 See Lack, et al., note 8 above and "Proceedings of the Deep Sea 2003 Conference", note 5 above. 
ensure sustainable fisheries and to avert serious ecosystem effects and biodiversity threats. ${ }^{32}$ Whereas the need for (more) national and international regulation of deep-sea fisheries is not challenged, diverging views abound as to the level at which regulation should take place and which form it should have. The discussion below develops the view that a multi-level approach is the most appropriate.

\section{A Multi-Level Approach}

The future national and international regulation of deep-sea fisheries can take many forms due to the wide choice of potentially effective (technical) measures and (more generally oriented) regulatory approaches. Which measures are appropriate for regulating deep-sea fisheries depends on many factors, most importantly on their spatial dimension and the level (national or international) at which they are adopted. Examples of possible measures are strict "no-take zones", area closures for certain fishing practices and areas with vertical zoning. ${ }^{33}$ The next three subsections address possible action at the global, regional and national levels.

\section{Action at the Global Level}

At present there is no single "purpose-built" global treaty or IO for high seas fishing in general or for discrete high seas fish stocks in particular. As the Fish Stocks Agreement does not apply to discrete high seas fish stocks, the international legal framework for these fisheries proceeds from rather general provisions of the LOS Convention, without the benefits of the progressive development of the law that has been achieved by means of the Fish Stocks Agreement. The question is therefore whether negotiations should be started to create such a global treaty ${ }^{34}$ and, if so, whether that global treaty should at the same time function as the constituent instrument for a single global fisheries management organisation (GFMO). It is submitted that in view of the urgent need for regulation of deep-sea fisheries and the considerable time that is likely to be involved in negotiating such a treaty, these approaches should not have the international community's priority. They should only be pursued after, or in tandem with, other global, regional or unilateral approaches that are likely to have more beneficial short-term impact on the regulation of deep-sea fisheries.

32 The conclusions by Lack, et al., note 8 above, at pp. iv and 57 are consistent with this view. See notes 106-112 below and accompanying text.

34 There are various processes that can be used to establish such a treaty, for instance amendment of the LOS Convention (cf. Art. 312), amendment of the Fish Stocks Agreement (cf. Art. 45), "implementation agreements" under the LOS Convention or the Fish Stocks Agreement or a single-standing instrument. 
The negotiation process for the LOS Convention (UNCLOS III) ${ }^{35}$ had very little support for the establishment of a single GFMO. ${ }^{36}$ This may to some extent have been motivated by a traditional (common and widespread) resistance against ambitious and comprehensive institutional reform, especially where the role and competence of existing institutions established pursuant to the then predominant piecemeal approach would be under threat. Such sentiments are likely to be widespread today as well. A lack of support then and now can furthermore be explained by a recognition that the regulation of marine fisheries will always require a strong regional component.

A different matter is the negotiation of a global treaty for high seas fisheries which would, similar to the Fish Stocks Agreement, require implementation at the regional level by means of (the establishment of) RFMOs. The circumstance that the treaty may also take considerable time to enter into force may perhaps be less problematic. Even prior to its entry into force, the Fish Stocks Agreement already had a large impact on the negotiation processes of the SEAFO Convention ${ }^{37}$ and the WCPFC Convention ${ }^{38}$ and the treaties that were eventually adopted. More problematic is the fact that the Fish Stocks Agreement has only relatively recently been adopted, and its status of participation and thereby its support does not yet come near that of the LOS Convention. ${ }^{39}$ Presumably, therefore, the most that the negotiation of a global treaty could at the moment hope for is essentially a mutatis mutandis application of some of the main provisions of the Fish Stocks Agreement. ${ }^{40}$ It could even be argued that some years are needed to consolidate the international law advances laid down in the Fish Stocks Agreement and to secure wider participation and support in it. Starting a related global negotiation process too early could even lead to a regression of the law. ${ }^{41}$

It is also questionable whether such a global treaty would really be necessary before action can be taken at the regional level. The negotiation and adoption of the Fish Stocks Agreement has not triggered a general overhaul of the constituent instruments of RFMOs that were already in existence prior to

Third United Nations Conference on the Law of the Sea

36 See, for instance, the proposals made by Lebanon (UN Doc. A/AC.138/SC.1/SR.17 of 9 August 1971) and by Mexico (UN Doc. A/AC.138/SC.II/SR.30 of 29 March 1972) with regard to an IO for high seas fisheries.

37 See note 25 above.

38 Convention on the Conservation and Management of Highly Migratory Fish Stocks in the Western and Central Pacific Ocean, Honolulu, 5 September 2000. In force 19 June 2004, (2001) 40 ILM 277; see also http://www.ocean-affairs.com.

39 Whereas the LOS Convention had by 16 January 2004 attracted 145 contracting parties, the Fish Stocks Agreement by that time had only 51.

40 Particularly relevant would seem to be Arts. 5, 6 and 8 and Annex II.

41 See in this respect W. Edeson, "Soft and Hard Law Aspects of Fisheries Issues: Some Recent Global and Regional Approaches" in Nordquist, Moore and Mahmoudi (eds.), The Stockholm Declaration and Law of the Marine Environment (The Hague, London, New York, Martinus Nijhoff Publishers, 2003), pp. 165-182. 
the negotiations. ${ }^{42}$ Instead of constitutional reform, most RFMOs seem nevertheless to adjust their practice to many aspects of the Fish Stocks Agreement. Furthermore, it seems reasonable to assume that those RFMOs with competence to deal with discrete high seas (deep-sea) fish stocks ${ }^{43}$ will manage these stocks on relevant aspects essentially similar to straddling fish stocks. It is admitted that in relation to discrete high seas stocks, RFMOs could not rely on provisions of the Fish Stocks Agreement which are unable to become customary international law or are unlikely to do so in the near future. Examples are the dispute settlement provisions and the technical intricacies of the provisions on non-flag state high seas enforcement. But, it is also submitted, existing RFMOs and negotiation processes to establish new RFMOs can by now quite safely rely on customary international law in applying concepts like the precautionary approach.

It is finally submitted that the legitimacy of RFMOs in managing marine capture fisheries is not, or is no longer, fundamentally challenged. The challenges that do arise relate to the consistency of their establishment with international $\mathrm{law}^{44}$ or the consistency of the adoption and application of their conservation and management measures with international law. In fact, challenges based on these grounds implicitly confirm the legitimacy of RFMOs and their competence to take or call for measures against (non-co-operating) non-members. ${ }^{45}$ This also suggests that the strengthened duty to co-operate with RFMOs pursuant to Article 8(3) of the Fish Stocks Agreement has already evolved into customary international law. ${ }^{46}$ However, an authoritative confirmation of the correctness of this assertion may not be available until such time that RFMOs accept the need for bolder measures against non-cooperating non-members, for instance through trade-related measures. As such measures could lead to the institution of proceedings under international trade

42 Exceptions are the complete revision of the IATTC Convention (Convention for the Establishment of an Inter-American Tropical Tuna Commission, Washington DC, 31 May 1949; in force 3 March 1950, 80 UNTS 4; http://www.iattc.org) by means of the Antigua Convention (Convention for the Strengthening of the Inter-American Tropical Tuna Commission Established by the 1949 Convention Between the United States of America and the Republic of Costa Rica, Washington DC, 14 November 2003; not in force, www.iattc.org) and the partial revision of the NEAFC Convention (see note 28 above and the agenda for the 22nd Annual NEAFC Meeting (2003) at http://www.neafc.org).

43 See notes 25-28 above and accompanying text.

44 See for instance note 95 below.

45 Cf. the reasoning of the International Court of Justice in the Case Concerning Military and Paramilitary Activities In And Against Nicaragua (Nicaragua v United States of America), Judgment (Merits) of 27 June 1986, [1986] ICJ Rep 98, para. 186.

46 See in this respect R.G. Rayfuse, Non-Flag State Enforcement in High Seas Fisheries (Leiden/Boston, Martinus Nijhoff Publishers, 2004), pp. 374-376 who comes to the same conclusion (see also pp. 82-100). The duty for states to take account of "generally recommended international minimum standards" pursuant to Art. 119(1)(a) of the LOS Convention may have contributed to this evolution. 
law, RFMOs need to be aware of the consequences of discrimination between members (or co-operating non-members) and (non-co-operating) non-members. ${ }^{47}$ RFMOs that do not have to fear such consequences would be acting in accordance with international law when combating unregulated fishing of discrete high seas (deep-sea) fish stocks.

There are several global bodies that could be turned to with the object of averting some of the sustainability and biodiversity threats posed by deep-sea fisheries. This is a consequence of the decentralised nature of international law and the absence of hierarchy among the various forms/manifestations of international law (e.g. treaties, custom, international judgments and acts of IOs) as well as among the various international law-making processes (e.g. IOs, international dispute settlement bodies and diplomatic conferences). The competence or mandate of many international bodies, including dispute settlement bodies, often overlap with each other. In order to minimise incompatibility, many international bodies have formal or informal co-ordination or primacy arrangements. ${ }^{48}$ As a consequence of new developments and changing needs and interests of the international community, both the competence of international bodies and these arrangements are in a constant state of flux. The choice for a particular international body, including dispute settlement bodies, to pursue a particular issue, is therefore often determined by considerations of international policy, politics and "forum-shopping". ${ }^{49}$

The usefulness of CITES ${ }^{50}$ in regulating trade in commercially exploited fish species has been the subject of heated debate in recent years. The suitability of the criteria used by CITES to determine the need for trade regulation for commercially exploited aquatic species is for instance questioned. ${ }^{51}$ One of the main problems is that where one or more stocks of such a species is/are healthy, this would make listing the entire species too general a tool. It is submitted that there are nevertheless situations where the interests of biodiversity outweigh those of exploitation. A different issue is that many states regard a

47 See the chapeau to Art. XX of the General Agreement on Tariffs and Trade (1947; http://www.wto.org). Reference should here also be made to the ongoing discussion in the World Trade Organization (WTO) Committee on Trade and Environment, Special Session, on the relationship between the WTO and Multilateral Environmental Agreements (MEAs) and the Specific Trade Obligations (STOs) incorporated therein.

48 E.g. Art. VI of the CCAMLR Convention, which acknowledges the primacy of the IWC; and IOTC (Indian Ocean Tuna Commission) Resolution 98/03 "On Southern Bluefin Tuna", which acknowledges the primacy of the CCSBT. See also notes 96 and 97 below and accompanying text.

49 For instance the efforts by Japan within the IOTC to establish a Working Party on Temperate Tunas, which would inter alia deal with southern bluefin tuna, even though that would lead to overlapping competence with the CCSBT (see IOTC Resolution 98/03)

50 Convention on International Trade in Endangered Species of Wild Fauna and Flora, Washington, DC, 3 March 1973. In force 1 July 1975, 993 UNTS 243; http://www.cites.org.

51 See in this respect the slow progress within FAO (Report of the 25th Session of COFI (2003, Doc. CL 124/7), paras. 46-50 and Appendices E, F and G and Doc. CL 124/7-Add.1). 
resort to CITES as a move that would undermine the authority and legitimacy of RFMOs and the FAO. ${ }^{52}$ This played a considerable role during COP12 to CITES (2002) when Australia proposed to list Patagonian and Antarctic toothfish (Dissostichus spp.) on Appendix II of CITES, but, faced by lack of support, eventually withdrew that proposal. ${ }^{53} \mathrm{~A}$ month or so prior to COP12, the Australian proposal had received practically no support at the 21st Annual CCAMLR Meeting (2002). ${ }^{54}$ The proposal may by some states also have been regarded as an unwelcome "external interference" in the Antarctic Treaty System (ATS), of which CCAMLR is part. Whereas the 25th Meeting (2003) of the FAO Committee on Fisheries (COFI) saw the "in principle" confirmation of the primacy of the FAO and RFMOs in fisheries conservation and management, it also recognised that a role for CITES is not excluded "in exceptional circumstances". 55

At least for the moment the emphasis is therefore on strengthening co-operation between CITES and FAO on the one hand and CITES and RFMOs like CCAMLR on the other hand. ${ }^{56}$ Unfortunately, at the 22nd Annual CCAMLR Meeting (2003) no progress was made on co-operation between CITES and CCAMLR.$^{57}$ In case an RFMO does not succeed in addressing sustainability and biodiversity concerns, such a lack of co-operation is expected to bolster the determination of those in favour of using CITES. ${ }^{58}$ Resort to CITES is

52 Similar issues of overlapping competence exist between CITES and the International Whaling Commission.

53 See listing proposal 39 (withdrawn). Some of the pro-whaling states that are members of CCAMLR also have other reasons for not using CITES.

54 For the discussion see Doc. CCAMLR-XXI, paras. 10.1-10.75. See also the observations in paras. 10.11 and 10.19 on the increased TAC for some stocks of Dissostichus spp. See also note 57 below with regard to the Australian proposal for the COP13 to CITES (2004).

55 See FAO Docs. CL 124/7, para. 47 and Appendix G, and CL 124/7-Add.1 (note 51 above).

56 See the proposals for co-operation between CITES and CCAMLR (Doc. COP12 16.1; adopted (Doc. COP12 Plen.7); Conference Resolution 12.4) and between CITES and FAO (Docs. COP12 16.2.1 and 16.2.2; adopted (Doc. COP12 Plen.7); COP Decisions 12.7) at the COP12 of CITES; see also COP Decisions 12.57-12.59.

57 See the Report of the 22nd Annual CCAMLR Meeting (2003, Doc. CCAMLR-XXII), paras. 14.1-14.19. However, the CITES Observer noted the possibility for states parties to CITES to unilaterally list species on Appendix III to CITES. Such action would, unlike Appendices I and II listing proposals, not require a two-thirds majority decision (see Arts. XV and XVI of CITES). However, in para. 4.16 Norway observed that "no Member [of CCAMLR] should bring about any decision on toothfish without a decision taken by [CCAMLR] by consensus", thereby emphasising the primacy of CCAMLR and rejecting the unilateral discretion of states that are parties to both CCAMLR and CITES. It seems that the Australian proposal to the COP13 of CITES (2004) to revise Conference Resolution 12.4 in order to provide for ongoing use by parties to CITES of CCAMLR's "Catch Documentation Scheme for Dissostichus spp." (CDS) is not inconsistent with the Norwegian view, even though the lack of prior consultation may not be appreciated.

58 See in this respect the discussion at the 21st Annual NEAFC Meeting (2002) (Report, pp. 37-38) on the Appendix II listing proposal by the United Kingdom (on behalf of all EU Member States) of basking shark (Cetorhinus maximus) at COP12. For a variety of reasons this proposal was, unlike the toothfish proposal, successful. 
nevertheless more likely to occur in situations where it would not lead to an actual overlap in competence with a concrete RFMO or an arrangement. However, as this would still trigger the more fundamental concerns about the roles of the FAO and RFMOs, the chance for such a scenario to materialise is slim. At least in the immediate future, the role of CITES may therefore be limited to that of the "bogeyman" for the FAO and RFMOs.

The reasons for the limited usefulness of the $\mathrm{CMS}^{59}$ for tackling unregulated deep-sea fisheries are in part similar to those of CITES. The scope of the CMS would certainly allow regulatory action by means of, inter alia, prohibitions of intentional taking, habitat protection and the development of agreements that do not merely deal with conservation but also with management, thus encompassing utilisation. ${ }^{60}$ However, as the regulatory approach under the CMS is, compared to that under CITES, therefore more similar in nature to that of RFMOs, the concerns about the roles of the FAO and RFMOs are even more pertinent. Resort to the CMS in the near future is therefore insufficiently plausible to exert a bogeyman effect.

A constraint on the usefulness of the Biodiversity Convention in tackling unregulated deep-sea fisheries is caused by the fact that, in areas beyond national jurisdiction, only the Convention's provisions on processes and activities carried out under the jurisdiction or control of states are applicable. ${ }^{61}$ This is a significant limitation as the Convention's obligations on processes and activities in Articles 3, 5, 7(c) and 8(1) are not very specific. However, as part of the COPs' efforts on the implementation of the Biodiversity Convention, such obligations could gradually become more specific. In this context, mention must be made of the Thematic Programme on the Conservation and Sustainable Use of Marine and Coastal Biological Diversity (Jakarta Mandate) ${ }^{62}$ and the recent COP7 (2004) Decision VII/5 on "Marine and Coastal Biological Diversity". ${ }^{33}$ The relevance of Decision VII/5 to unregulated deep-sea fisheries is twofold. First, it gives higher priority to marine protected areas (MPAs) beyond areas of national jurisdiction. ${ }^{64}$ The UNGA is nevertheless regarded as

59 Convention on the Conservation of Migratory Species of Wild Animals, Bonn, 23 June 1979. In force 1 November 1983, reproduced in 1651 UNTS 355; see also http://www. wcmc.org.uk/cms/.

60 See the definitions in Art. I(1)(a), (f), (h) and (i), the listing under Art. III and the agreements under Arts. IV and V. It is worth noting that none of the agreements that have so far been established under Art. IV have a utilisation component. See http://www.wcmc.org.uk/cms/ for an overview of these agreements.

61 Art. 4.

62 The programme of work for the Jakarta Mandate was first adopted at COP4 (1998) but has been elaborated at later COPs, lastly at COP7 (2004) by Decision VII/5.

63 See note 6 above.

64 Paras. 29-31 and Operational Objective 3.2 in Annex I. See also Decision VII/28 on "Protected Areas (Articles 8(A) to (E))", paras. 26-31 and 36-37 and Goals 1.1.3 and 1.3 of the Annex. 
the body with primary responsibility to develop an appropriate mechanism for the establishment of such MPAs. Secondly, it responds to UNGA Resolution $58 / 240$ by separately addressing the issue of "Conservation and Sustainable Use of Biological Diversity in Marine Areas Beyond the Limits of National Jurisdiction". ${ }^{65}$ Apart from action within the UNGA and other IOs, parties to the Biodiversity Convention are also recommended to "urgently take the necessary short-term, medium-term and long-term measures to respond to the loss or reduction of marine biological diversity" in areas beyond national jurisdiction resulting from processes and activities. Whereas these two tiers undoubtedly give the need to address unregulated deep-sea fisheries a higher profile and priority, they still suffer from the same lack of specificity as the cited provisions of the Convention. Whether future COPs of the Biodiversity Convention will address that shortcoming is uncertain. As COP8 is scheduled to take place in 2006 it is unrealistic to hope for short-term results.

COP7 to the Biodiversity Convention seems to confirm that meaningful short-term global action on unregulated deep-sea fishing is most likely to come from the UNGA. The IPC process may play an important complementary role, inter alia in generating support for action by the UNGA. Action by the UNGA could take place in many forms. One would be to adopt a (non-legally binding) resolution calling for a moratorium on certain types of deep-sea fishing, for example for bottom trawling on seamounts, deep-water coral reefs and other biodiversity hotspots. ${ }^{66}$ This course of action would be inspired by the UNGA's instrumental role in establishing a global moratorium on large-scale pelagic drift-net fishing on the high seas. ${ }^{67}$ How broad in scope (geographically as well as substantively) and how restrictive such a resolution would be depends largely on how much international support would be available. The UNGA resolutions on drift-net fishing managed to attract practically universal support due to the wide recognition of the non-sustainability and wastefulness of these practices as well as the relatively limited financial interests involved. Similar wide recognition and limited financial interests may not exist vis-à-vis deep-sea fishing or even specifically deep-sea bottom trawling. This means that a resolution may have to be watered down in terms of its scope and stringency in order to gain sufficient support.

UNGA resolutions that cannot be adopted without a vote or that attract a significant number of votes against are still passed in accordance with the decision-making procedures, ${ }^{68}$ but may eventually be unable to ensure

65 Paras. 57-62 and Operational Objective 2.4 in Annex I.

${ }_{66}$ See M. Gianni, "High Seas Bottom Fisheries and Their Impact on Vulnerable Deep-Sea Ecosystems: Preliminary Findings", paper submitted to the 58th Meeting of the UNGA (2003), UN Doc. A/58/95, note 3 above, para. 87, p. 25 and UN Doc. A/58/65, note 3 above, paras. 183 and 230 , pp. 56 and $67-68$.

67 See inter alia UNGA Resolutions 44/125, 45/197 and 46/215. 68 Cf. Art. 18 of the UN Charter.
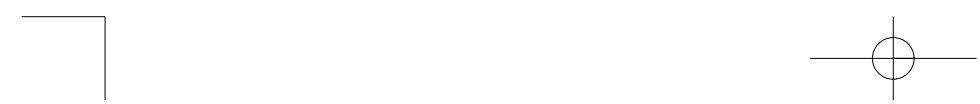
sufficient universal support, and thereby authority, to lead to universal implementation. While this may be true, even an UNGA resolution that lacks universal support can make a contribution to enhancing awareness and to creating stimulus and legitimacy for further action at the regional and national levels. ${ }^{69}$ One important consideration in this context is that the urgency by which deepsea fishing needs to be addressed may be even higher than with drift-net fishing. This urgency means that a strong resolution with less than universal support may be preferable above a weak resolution that enjoys universal support. Whereas the need for expediency would imply that an UNGA resolution should at any rate contain short-term results, this does not exclude complementary medium- and long-term objectives. The call for measures at the short, medium and long term in COP7 Decision VII/5 takes a similar approach. This could for instance include the negotiation of a high seas fisheries treaty which acts as the constituent instrument of a GFMO, mentioned at the outset of this section.

\section{Action at the Regional Level}

A regional approach to addressing the absence of regulation of deep-sea fisheries appears both logical and suitable, whether or not pursued in tandem with a global approach through the UNGA. As was argued above, action at the regional level does not have to await the adoption or entry into force of a global treaty modeled on the Fish Stocks Agreement. Those RFMOs that already have competence to regulate discrete high seas deep-sea fish stocks should therefore immediately use this competence to assess a need for regulation and, in case this need has been ascertained, to expeditiously commence regulation consistent with the Fish Stocks Agreement. More problematic are situations where no existing RFMOs have competence spatially or substantively (species) due to the range of distribution and the type of deep-sea fish stocks. As the negotiation process for SWIOFC illustrates to some extent, the urgent need for regulation may render the negotiation of a classic-style RFMO an inadequate solution. An alternative would be an "arrangement" within the meaning of Article 1(1)(d) of the Fish Stocks Agreement. This provision defines an arrangement as:

a cooperative mechanism established in accordance with the [LOS] Convention and this Agreement by two or more States for the purpose, inter alia, of establishing conservation and management measures in a subregion or region for one or more straddling fish stocks or highly migratory fish stocks.

69 The UNGA Resolution should in fact anticipate this by providing guidance to authorities at the regional and national levels as to what types of action should be taken and which criteria or other considerations should be taken into account. See in this regard the observations on discrimination at the end of the section on "Unilateral Action at the National Level". 
This clearly allows for many different types of arrangements, provided the general condition of consistency with international law is met and the arrangement's purpose falls within the scope of the Fish Stocks Agreement. This does not prevent states from establishing arrangements with a purpose that does not fall within the scope of the Fish Stocks Agreement, for instance because they deal with discrete high seas stocks. Such arrangements must nevertheless comply with other rules of international law, including the LOS Convention and customary international law. Moreover, as the 2000 South Tasman Rise Orange Roughy Arrangement illustrates, an arrangement does not necessarily have to be laid down in a treaty. ${ }^{70}$ It is submitted that compared with RFMOs, establishing arrangements may often have more benefits in relation to expeditiousness, flexibility and expenses.

One possible regional approach is to use the co-operative framework of an existing RFMO to establish such an arrangement. Here again, many different approaches are possible. An interesting case is that of the regulation of Patagonian toothfish (Dissostichus eleginoides) under the CCAMLR Convention. The regulatory scope of the CCAMLR Convention, and thereby the competence of CCAMLR, is set out spatially and substantively in Articles I and II. The basis of its spatial competence is an approximation of the Antarctic Convergence, ${ }^{71}$ which separates the warmer northern waters from the cooler southern waters. The CCAMLR Convention Area is therefore regarded as one of the few RFMOs whose regulatory area largely overlaps with that of a large marine ecosystem (LME) ${ }^{72}$ with all the consequential advantages that should bring for ecosystem-based management. In reality, however, several species managed by CCAMLR also occur outside the Convention Area, either as transboundary or as discrete stocks. In the latter case, stocks may be discrete to the high seas (outside the Convention Area) or to coastal state maritime zones or they may be straddling stocks between these areas. ${ }^{73}$ Occurrence beyond the Convention Area is particularly relevant for Patagonian toothfish. Article XI of the CCAMLR Convention addresses a part of this problem by

70 This is inter alia supported by the systematic use of "will" instead of "shall" throughout the text of the Arrangement.

1 Art. I.

72 See LME no. 61, "Antarctic" at http://www.edc.uri.edu/lme.

73 See the discussion at the 22nd Annual CCAMLR Meeting (2003) as to whether or not Patagonian toothfish in the Indian Ocean should be treated as a metapopulation and, consequently, as a straddling stock (Doc. CCAMLR-XXII, paras. 11.2-11.3). See note 2 above on the use of the term "straddling stock". The CCAMLR Commission may eventually embrace this metapopulation theory by concluding that the transboundary effects caused by the exchange of individuals between the various populations is such that they should no longer be exclusively managed as discrete stocks. Embracing this approach may have important consequences for coastal states with relevant maritime zones inside and outside the Convention Area and for the evolution of the competence of CCAMLR, both substantially and geographically. 
requiring CCAMLR to co-operate with coastal states with a view to harmonising conservation for transboundary stocks between the Convention Area and coastal states maritime zones beyond the Convention Area. ${ }^{74}$

Faced with very serious IUU fishing problems, CCAMLR realised that the high seas dimension of the problem also needed to be addressed. In addition to adopting four (non-legally binding) CCAMLR Resolutions, ${ }^{75}$ the main measure so far has been the regulation of trade in toothfish through the CDS. ${ }^{76}$ The main objective of the CDS is to determine whether toothfish is caught in a manner consistent with CCAMLR's Conservation Measures. All toothfish transshipped, landed in ports, imported, exported or re-exported must be accompanied by a completed and validated Dissostichus catch document (DCD).

Whereas contracting parties to the CCAMLR Convention are legally bound to these specific obligations under the $\mathrm{CDS},{ }^{77}$ if non-contracting parties or their vessels want to engage in some of these activities, in particular export, they are effectively forced to participate in the CDS. Several non-contracting parties therefore currently participate on a voluntary basis in the CDS. ${ }^{78}$ Obviously, however, if toothfish is caught in contravention of CCAMLR's Conservation Measures, in particular if it is caught inside the Convention Area by an unlicenced vessel, ${ }^{79}$ the DCD will not be accepted. If, on the other hand, the DCD indicates that the catches were made outside the Convention Area, whether on the high seas or within coastal state maritime zones, the DCD must in principle be accepted in view of the sovereignty, sovereign rights and high seas freedoms related to fishing under international law. As a consequence, however, CCAMLR had implicitly started to regulate fishing activities outside the Convention Area. ${ }^{80}$ The experience in the operation of the CDS so

74 Whether or not as straddling stocks pursuant to Art. 63(2) of the LOS Convention. See also note 73 above.

75 Resolution 10/XII on "Harvesting of Stocks Occurring Both Within and Outside the Convention Area", Resolution 16/XXII "Application of VMS outside the Convention Area in the Catch Documentation Scheme", Resolution 17/XX "Use of VMS and other Measures for the Verification of CDS Catch Data for Areas Outside the Convention Area, in particular, in FAO Statistical Area 51" and Resolution 18/XXI on "Harvesting of Dissostichus eleginoides in Areas Outside of Coastal State Jurisdiction adjacent to the CCAMLR Area in FAO Statistical Areas 51 and 57".

76 See note 57 above. Currently laid down in Conservation Measure 10-05 (2003).

77 Although the CDS is explicitly directed towards contracting parties, only members of the Commission are formally and legally bound by Conservation Measures. See in this regard Art. XXII of the CCAMLR Convention and CCAMLR Resolution 14/XIX "Catch Documentation Scheme: Implementation by Acceding States and Non-Contracting Parties".

78 See Doc. CCAMLR-XXII/BG/18 Rev. 1 of 21 October 2003, "Implementation and Operation of the Catch Documentation Scheme in 2002/03 (Secretariat)".

79 Vessels of non-contracting parties will always be regarded as unlicenced.

80 At the 18th Annual CCAMLR Meeting (1999), when the CDS was adopted, this was not seen as a major obstacle (see the Report, paras. 5.10-5.43, in particular paras. 5.36 and $5.38-5.41)$. 
far has demonstrated a serious suspicion that much of the toothfish reported in DCDs as caught on the high seas outside the Convention Area, is in reality caught inside the Convention Area ${ }^{81}$ Whereas the $\mathrm{CDS}^{82}$ and CCAMLR Resolutions 16/XXII and $17 / \mathrm{XX}^{83}$ recognise the discretion of states, in particular in their capacity as port state, to require additional verification of DCDs for catches on the high seas outside the Convention Area, inter alia by means of satellite-based vessel monitoring system (VMS) data, there is no legally binding obligation to do so. Attempts to address these problems at the $21 \mathrm{st}$ and 22nd Annual CCAMLR Meetings (2002 and 2003) by means of more explicit regulation beyond the Convention Area were largely unsuccessful.

At the 21st Meeting, Australia proposed that the spatial scope of the CCAMLR Convention be amended to include certain areas of the Indian Ocean. In addition or alternatively, it was proposed that CCAMLR adopt the necessary conservation measures to regulate fishing in the high seas parts of these areas. ${ }^{84}$ The first proposal attracted no support whatsoever and the alternative proposal was not discussed ${ }^{85}$ Some delegations noted that the process of amending the CCAMLR Convention pursuant to its Article XXX would be a lengthy one and possibly unsuccessful as it requires formal adherence by all Commission members. Other delegations noted that a northward extension would encroach on the competence of other RFMOs. Some members may have even regarded a northward extension as ipso facto inappropriate as the Antarctic Convergence would then no longer be the only rationale for the spatial scope of the CCAMLR Convention. In the negotiations on the CCAMLR Convention, the Antarctic Convergence and the ecosystem approach became the rationale for the significant extension north of the Antarctic Treaty area, whose northern boundary is $60^{\circ}$ South latitude. ${ }^{86}$ The boundary eventually agreed on largely adopted pre-existing FAO Statistical Areas based on an approximation of the Antarctic Convergence. ${ }^{87}$ However, the Special Antarctic

81 See inter alia CCAMLR Resolution 18/XXI, note 75 above; Doc. CCAMLR-XX (2001), paras. 5.12-5.18; and Doc. CCAMLR-XXI (2002), paras. 8.2-8.8.

82 See paras. 14 and A3.

83 See note 75 above.

84 Doc. CCAMLR-XXI/24 of 18 October 2002, "Achieving Sustainable Fisheries for Dissostichus spp.: Managing the Harvesting of Stocks Outside the CCAMLR Area" (Delegation of Australia). This proposal built on discussions at the 20th Annual CCAMLR Meeting (2001) (see Doc. CCAMLR-XX, paras. 7.18-7.20).

85 See Doc. CCAMLR-XXI (2002), paras. 8.74-8.84

86 Art. VI of the Antarctic Treaty. See in this context J.N. Barnes, "The Emerging Convention on the Conservation of Antarctic Marine Living Resources: An Attempt to Meet the New Realities of Resource Exploitation in the Southern Ocean" in J.I. Charney (ed.), The New Nationalism and the Use of Common Spaces (Allanheld, Osmun Publishers, 1982), pp. 239-286, at p. 250 , n. 66.

87 Cf. Barnes, note 86 above, p. 261. See the historical FAO statistical charts at www.fao.org/fi/ statist/statist.asp. J.M. Johanson, "The CCAMLR Ecosystem Approach to the Management of Marine Harvesting" (unpublished PhD thesis, University of Tasmania, 1997), at p. 28 notes that the FAO relied in part on recommendations by SCAR (Scientific Committee on Antarctic Research). See also note 89 below. 
Treaty Consultative Meeting that was charged with developing the draft CCAMLR Convention, was obliged to take into account several elements, one of which was that "the regime should, however, extend north of $60^{\circ}$ South latitude where that is necessary for the effective conservation of species of the Antarctic ecosystem" (emphasis added) ${ }^{88}$ Moreover, the agreed approximation of the Antarctic Convergence also took account of political considerations, thereby causing a small diversion from pre-existing FAO Statistical Areas. ${ }^{89}$

At the 22nd Meeting, Australia, New Zealand and the United States submitted a proposal for a centralised VMS (CVMS) which would also apply to fishing for toothfish outside the Convention Area. ${ }^{90}$ Rather than amending the CCAMLR Convention, this proposal envisaged a conservation measure that would either apply explicitly outside the Convention Area or implicitly by means of a linkage with the CDS. ${ }^{91}$ This time the objections not only related to other RFMOs with competence but also alluded to CCAMLR's lack of (spatial) competence. ${ }^{92}$ In the end, even a watered-down proposal whose scope was limited to the Convention Area was unable to attract consensus. ${ }^{93}$

The lack of consensus on these 2002 and 2003 proposals seems to indicate that whereas CCAMLR members were prepared to accept the implicit approach pursued by the CDS in 1999, the explicit approach pursued by these recent proposals secured no consensus. It is submitted that some of the objections that were raised are more convincing than others. As regards conflicting or overlapping competence with other RFMOs, it should be recognised that the establishment of SWIOFC may not just still take considerable time but may not even happen at all. Also, even if the Galapagos Agreement ${ }^{94}$ indeed enters into force and becomes fully operational, some CCAMLR members

88 Antarctic Treaty Consultative Meeting Recommendation IX-2 (1977), under III(3)(e).

89 Barnes, note 86 above, at p. 262 observes that at the insistence of Argentina, the boundary was drawn further away from Argentine territory in order to exclude the Drake Passage (FAO statistical charts were later modified accordingly (see note 87 above)). This is also mentioned by F.M. Auburn, Antarctic Law and Politics (Bloomington, Indiana University Press, 1982), at pp. 134-135. However, his opinion on p. 292 that the exclusion of Macquarie Island and its maritime zones benefited Australia is, inter alia in view of the Statement by the Chairman of the Conference on the Conservation of Antarctic Marine Living Resources, not really convincing.

90 Docs. CCAMLR-XXII/54 of 10 October 2003 and CCAMLR-XXII/BG/21 of 15 October 2003.

91 Draft Conservation Measure 10-04 of 29 October 2003 (Australia, New Zealand, USA) (on file with author).

92 See Doc. CCAMLR-XXII/59 of 3 November 2003, Report of the Standing Committee on Implementation and Compliance (SCIC), paras. 3.27-3.54, in particular paras. 3.32-3.33.

93 See Doc. CCAMLR-XXII, note 57 above, paras. 10.12-10.23. Argentina proved to be the main, if not only, bar to consensus, probably mainly because it saw the proposal as affecting its sovereignty in the context of the sovereignty dispute between Argentina and the United Kingdom over South Georgia, the South Sandwich Islands and Shag Rocks (para. $10.21)$.

94 See note 25 above. 
may not regard it as a "competent" organisation in view of the substance of the Agreement as well its negotiation process. ${ }^{95}$ Lastly, while the SEAFO Convention has recently entered into force, it will take some time for it to become fully operational. And even when that moment has arrived, its membership may decide to recognise the primacy of CCAMLR in regulating toothfish. ${ }^{96}$ And even if CCAMLR were to adopt conservation measures whose spatial scope would overlap with the proposed regulatory area of another RFMO, it could specifically indicate that these are to be withdrawn when that RFMO, once established, so wishes. It is to be hoped that such an RFMO does not request such a withdrawal until such time that it is capable of managing the fish stocks with comparable effectiveness and that the two RFMOs establish co-operative arrangements to ensure compatibility in their management. ${ }^{97}$

As regards the formal competence of CCAMLR, it has to be admitted that the relevant provisions of the CCAMLR Convention leave very little room for an extensive purposive or "implied powers" interpretation. Even though Article I(1) and (2) of the CCAMLR Convention provide that it applies to "Antarctic marine living resources", this is firmly linked to the spatial scope of the Convention. Moreover, the Convention's objective of "the conservation of Antarctic marine living resources" in Article II(1) must be interpreted in light of Article I(1) and (2). The function or mandate of CCAMLR laid down in Article IX(1) is to give effect to the Convention's objective and is thereby also linked to Article I(1) and (2). The residual tasks and types of Conservation Measures under Article IX(1)(h) and (2)(i) and CCAMLR's obligations to co-operate with coastal states under Article XI and with relevant IOs (including RFMOs) under Article XXIII(3) and (4), do not warrant a different conclusion either.

It seems also likely that some CCAMLR members were concerned about potential implications beyond CCAMLR if a strict treaty interpretation were not to be followed. The many competence issues which have arisen under the IWC Convention ${ }^{98}$ in recent years are just one example. ${ }^{99}$ Having said that,

95 See Molenaar, note 24 above, pp. 102-103. Note, for instance, that the Japanese statement in para. 3.32 of Doc. CCAMLR-XXII/59, note 92 above, refers to SEAFO and SWIOFC but not to the Galapagos Agreement.

96 See also A. Serdy, "One Fin, Two Fins, Red Fins, Bluefins: Some Problems of Nomenclature and Taxonomy Affecting Legal Instruments Governing Tuna and Other Highly Migratory Species", (2004) 28 Marine Policy 235-247 at p. 242, n. 24 and accompanying text on the original ICCAT (International Commission for the Conservation of Atlantic Tunas) statistical document and its application to southern bluefin tuna beyond ICCAT's regulatory area.

97 Note in this regard the co-operation between NAFO and NEAFC with regard to the management and conservation of oceanic redfish (see, e.g., the Report of the 20th Annual NEAFC Meeting (2001), p. 6; and NAFO's 2001 Annual Report, pp. 51-60).

98 International Convention for the Regulation of Whaling, Washington DC, 2 December 1946. In force 10 November 1948, 161 UNTS 72; www.iwcoffice.org.

99 For instance on the "Berlin Initiative on Strengthening the Conservation Agenda of the International Whaling Commission" (as adopted by IWC Resolution 2003-1); on the competence of the International Whaling Commission to decide on requests for adherence to the IWC Convention (see Chair's Report of the 53rd Meeting, pp. 12-15 and the info related to 
one fundamental difference between the IWC Convention and the CCAMLR Convention is that decision-making in the former occurs by simple or qualified majority. Consensus decision-making within the CCAMLR Convention at least guarantees the widest possible support. One possible solution to the lack of formal competence would be, as suggested at the beginning of this subsection, to use the co-operative framework of CCAMLR to establish an arrangement. Whereas CCAMLR would function as a forum to negotiate such an arrangement, its adoption would take place according to independent procedures. As already noted above, such an arrangement must be consistent with international law, including the LOS Convention and customary international law. Most importantly, it should be non-discriminatory, open to new participants and based on an equitable distribution of fishing opportunities. The adoption of such an arrangement would attest to the CCAMLR member's willingness to provide flexible and expeditious solutions to pressing problems. Such action would also allow CCAMLR to reassert its position as a pioneering and leading RFMO - a position that has been under increasing pressure in recent years. While the specifics of CCAMLR's lack of competence are probably unique to CCAMLR, the proposed solution is relevant for many different lack-of-competence scenarios. The envisaged action by CCAMLR may therefore also inspire others to adopt the flexible and expeditious solutions that the regulation of deep-sea fisheries so desperately needs.

\section{Unilateral Action at the National Level}

States can choose from a wide range of unilateral regulatory approaches that can benefit the sustainability of deep-sea fisheries and safeguard biodiversity. However, where these are based on a state's jurisdiction under the nationality principle (including flag state jurisdiction), there are of course economic implications. The domestic fishing industry is likely to regard stringent unilateral regulation or a prohibition of (certain) deep-sea fisheries as unfair in view of the competitive advantages for states regulating less stringently or not at all. The effectiveness of such unilateral regulation may also be insufficient. However, a lack of effective national or international regulation cannot serve as an excuse for continuing to engage in fishing activity that is inconsistent with obligations under international law for being both unsustainable and for the threat it poses to biodiversity. Action at the global level, for instance through a resolution by the UNGA, would be helpful as it would remind states of their obligations and thereby contribute towards creating a level playing field.

cont.

the Icelandic adherence at www.iwcoffice.org); and on the objective of special permit scientific whaling under Art. VIII of the IWC Convention (see section 6.2 and Appendices 2 and 3 to Annex O of the 2002 Report of the IWC Scientific Committee). 
One approach to regulating or prohibiting high seas bottom trawling that would not be affected by open access and "free rider" problems relies on a coastal state's sovereign rights over its continental shelf. This option would be available to states that have not yet established an EEZ or exclusive fishing zone (EFZ), for instance many coastal states in the Mediterranean Sea. It would also be available to states with a so-called outer continental shelf: that is, that part of the legal continental shelf extending beyond 200 nautical miles from the baseline in accordance with Article 76 of the LOS Convention. ${ }^{100}$

A coastal state has sovereign rights over its continental shelf "for the purpose of exploring it and exploiting its natural resources". ${ }^{101}$ These natural resources consist of the non-living resources of the sea-bed and subsoil together with living organisms belonging to sedentary species. ${ }^{102}$ The latter are defined as "organisms which, at the harvestable stage, either are immobile on or under the sea-bed or are unable to move except in constant physical contact with the sea-bed or the subsoil". 103

While it is generally accepted that this would include species like clams and abalone, for other species this is not so clear. ${ }^{104}$ The notion of "sovereign rights" falls short of full sovereignty, but comprises comprehensive jurisdiction with a scope that is identical to the scope of the sovereign rights. ${ }^{105}$ Article 78(2) of the LOS Convention stipulates that coastal states are not to exercise their sovereign rights in a way that would infringe or result in unjustifiable interference with the rights and freedoms of other states.

As mentioned before, it is submitted that these sovereign rights can also be used to regulate or prohibit deep-sea fisheries that use bottom trawling, for instance to protect deep-water coral reefs (e.g. Lophelia pertusa) or benthic communities. ${ }^{106}$ To protect these, such fishing practices have occasionally been

100 The implications of taking such action before the coastal state has established the outer limits of the outer continental shelf on the basis of the recommendations of the Commission on the Limits of the Continental Shelf (CLCS) pursuant to Art. 76(8) of the LOS Convention are complex issues that cannot be discussed here. It is nevertheless submitted that in many circumstances and locations this requirement does not prevent the coastal state from the types of action envisaged in this subsection.

101 Art. 77(1) of the LOS Convention.

102 Art. 77(4) of the LOS Convention.

103 Ibid.

104 E.g. in 1962-63, disagreement over the categorisation of lobster led to the so-called lobster war between Brazil and France (cf. J.A. de Yturriaga, The International Regime of Fisheries. From UNCLOS 1982 to the Presential Sea (The Hague/Boston, Martinus Nijhoff Publishers, 1997), p. 109), and in 1994, when Canada and the United States disagreed on the categorisation of scallops (see (1995) 10 IJMCL 221-222).

${ }^{105} \mathrm{Cf}$. the Commentary by the International Law Commission (ILC) (Yearbook of the International Law Commission (1956), vol. II, p. 297) on what would become Art. 2(1) of the Convention on the Continental Shelf (Geneva, 29 April 1958; in force 10 June 1964, reproduced in 499 UNTS 311; text also available at http://www.un.org/law/ilc). Art. 2 was reproduced almost verbatim in Art. 77 of the LOS Convention.

106 See in general R. Long and A. Grehan, "Marine Habitat Protection in Sea Areas under the 
prohibited within EEZs or EFZs. For instance, in 1999 Norway commenced with identifying deep-water coral reefs within its EEZ and subsequently protected them by prohibiting the use of fishing gear that is dragged along the bottom. At the time of writing, the protected reefs include the Sula ridge, the Iver ridge and the Røst reef, the world's largest cold-water reef. ${ }^{107}$ On 19 May 1999 Australia proclaimed the Tasmanian Seamounts Marine Reserve in which all trawling deeper than 500 metres below the ocean's surface was prohibited to protect benthic coral- and urchin-dominated communities as from 2 August 1999. ${ }^{108}$ In July 2001 Sweden prohibited bottom trawling in parts of the Kosterfjord area, which are either within Sweden's territorial sea or its internal waters. ${ }^{109}$ Finally, the EU banned bottom trawling in the area of the Darwin Mounds, north-west of Scotland, in $2003^{110}$ and proposed a similar ban in areas around the Azores, Madeira and the Canary Islands in 2004. ${ }^{111}$ It is worth noting that the Autonomous Region of the Azores brought an action against the EU Council in relation to another Council Regulation, ${ }^{112}$ arguing inter alia that it will have a devastating effect on the status of deep-sea species in the outer 100 or 150 nautical miles of the EEZ around the Azores. ${ }^{113}$

So far, however, there does not seem to have been an exercise of sovereign rights over the continental shelf in the circumstances envisaged in this subsection, that is, in the absence of an EEZ or EFZ or on the outer continental shelf. It is nevertheless submitted that international law, including the LOS

cont.

Jurisdiction of a Coastal Member State of the European Union: The Case of Deep-Water Coral Conservation in Ireland", (2002) 17 IJMCL 235-261.

107 Information provided by T. Løbach, September 2003. See also Seabed News, No. 1 (July 2000), p. 1 (available at www.eu-seased.net).

108 Commonwealth of Australia Gazette, No. GN 20, 19 May 1999. See info at www.ea.gov.au/coasts/ $\mathrm{mpa} / \mathrm{seamounts}$.

109 T. Lundälv, "Conservation Issues Relating to Deep-Water Corals in the Kosterfjord Area, NE Skagerrak", in: Final Report of the ACES (Atlantic Coral Ecosystem Study) Consortium to the European Commission, 2003.

110 Cf. Commission Regulation (EC) No. 1475/2003 of 20 August 2003, on the Protection of Deep-Water Coral Reefs From the Effects of Trawling in an Area North-West of Scotland (OJ 2003 No. L211/14); Commission Regulation (EC) No. 263/2004 of 16 February 2004, extending for six months the application of Regulation (EC) No. 1475/2003 on the Protection of Deep-Water Coral Reefs From the Effects of Trawling in an Area North-West of Scotland (OJ 2004 No. L46/11); and Council Regulation (EC) No. 602/2004 of 22 March 2004, amending Regulation (EC) No. 850/98 as regards the Protection of Deep-Water Coral Reefs From the Effects of Trawling in an Area North-West of Scotland (OJ 2004 No. L97/30).

111 See COM (2004) 58 final of 3 February 2004, "Proposal for a Council Regulation Amending Regulation (EC) No 850/98 as regards the Protection of Deep-Water Coral Reefs From the Effects of Trawling in Certain Areas of the Atlantic Ocean".

112 Council Regulation (EC) No. 1954/2003 of 4 November 2003, on the Management of the Fishing Effort Relating to Certain Community Fishing Areas and Resources and modifying Regulation (EC) No. 2847/93 and repealing Regulations (EC) No. 685/95 and (EC) No. 2027/95 (OJ 2003 No. L289/1).

113 Case T-37/04, before the Court of First Instance of the EC (OJ 2004 No. C94/47). See also info at http://www.seas-at-risk.org. 
Convention, would not only allow an exercise of these sovereign rights for this purpose but would in fact now and then require this. As regards the scope of the sovereign rights, the purpose of "exploring it and exploiting its natural resources" would by implication allow the coastal state to prohibit any exploring or exploitation whatsoever, and thereby preserve the natural resources. ${ }^{114}$ However, whereas the definition of natural resources in paragraph (4) of Article 77 includes all non-living resources, the only living organisms explicitly included are those belonging to sedentary species. The rationale for the inclusion of sedentary species can partly be explained by their limited mobility at the harvestable stage. As their exploitation would have only minimal transboundary impacts, there was no need for international co-operation in management and conservation. It was generally accepted that demersal fish species would not fall within this category. ${ }^{115}$

Coral reefs can be argued to fall within the definition of natural resources for the reason that they consist of both living and non-living components. It is argued, however, that the words "at the harvestable stage" should not be interpreted in a way that would exclude benthic organisms that are not (yet) intended for exploitation. Such an interpretation would not be consistent with the above-mentioned rationale. Consequently, it is submitted that the sovereign rights under Article 77 can also be used to preserve such organisms and protect them from interference. States wishing to prohibit bottom trawling or other fishing practices that have adverse impacts on the natural resources of their continental shelf, including sedentary species, should also point to their obligations under international law and emphasise that such action would respond to the growing concern of the international community on these issues. ${ }^{116}$ Here too, action at the global level, inter alia through a resolution of the UNGA, would be helpful to support states that contemplate such action.

Finally, it should be emphasised that Articles 78(2) and 300 of the LOS Convention require coastal states to ensure non-discrimination in the exercise of their sovereign rights. This is necessary in two distinct situations. In the first, coastal state regulation on the (outer) continental shelf must apply equally to foreign and national vessels. In the second, the stringency of coastal

114 Cf. Art. 77(2) of the LOS Convention.

115 Cf. ILC Yearbook, vol. II, p. 297. See also the discussion in de Yturriaga, note 104 above, pp. $106-110$

116 These obligations are set out in the section on "The Present International Legal Regime and State Practice". It should be noted that Part XII of the LOS Convention does not provide coastal states with more comprehensive rights over a wider range of natural resources than pursuant to Parts V and VI. The fact that Part XII imposes many obligations with respect to the marine environment (a term not defined by the LOS Convention) on (coastal) states, cannot alter that. Consequently, even if certain fishing practices could be classified as "pollution of the marine environment" (see Art. 1(1)(4) of the LOS Convention), which is tenuous at best, provisions like Art. 208 would still not give coastal states broader jurisdiction than under Arts. 56 or 77. 
state regulation must be uniform in all its maritime zones. An unjustifiable or arbitrary higher level of stringency in regulation on the (outer) continental shelf in comparison with maritime zones where foreign vessels have no fishing access, would give national vessels a competitive advantage and thereby discriminate against high seas fishing states.

\section{Conclusions and Observations}

If the gradual worsening of the current worldwide crisis in marine capture fisheries is to be reversed, states have to be progressive, pro-active and precautionary, whether at the national, regional or global level. If ever there were a need for such a course of action, it would be for the regulation of deep-sea fisheries now. In view of the special characteristics of deep-sea fisheries, the current international legal regime and relevant state practice, regulatory action needs to be taken with the utmost urgency. As there may not be enough time for conceptually sound and holistic but incremental processes for regime building, the focus should first of all be on flexible short-term action.

The approach advocated in this article would be one where complementary action is taken simultaneously at the global, regional and national level. Efforts at the global level should first of all be directed through the UNGA to enhance awareness and to create the necessary stimulus and legitimacy for further action at the regional and national level. In view of the urgency of the matter, priority should not be given to start a negotiation process for a global treaty modeled on the Fish Stocks Agreement. Under the current circumstances, the outcomes of such a process are expected to be modest at best. Moreover, even without such a global treaty, the regulation of discrete high seas (deep-sea) fish stocks would still be possible on the basis of customary international law. This basis can be relied on not only for such concepts as the precautionary approach but also for the fundamental role and authority of RFMOs in fisheries management and their ability to call for or take action against (non-co-operating) non-members.

At the regional level, urgency requires that efforts should initially not be aimed at establishing new RFMOs but instead at more flexible and expeditious options, for instance concluding arrangements, treaty or non-treaty and within or outside the co-operative framework of existing RFMOs. It is to be hoped that CCAMLR can play a leading and guiding role in this regard.

One option for unilateral action discussed in this article would be available for coastal states that have yet to declare an EEZ or an EFZ or that have a continental shelf beyond 200 nautical miles from their baselines. Such states should exercise, in a non-discriminatory manner, their sovereign rights to regulate or prohibit bottom trawling and other fishing practices that have adverse impacts on the natural resources of their continental shelf. 